I thank Professor $\mathrm{R} W$ Stout for permission to report this case and for his helpful advice.

1 Trinder P. Rapid determination of salicylate in biological fluids. Biochem $\mathfrak{f}$ 1954;57:301-3.

2 Aylward M. Toxicity of benorylate. Br Med 7 1973;iii:347-8.

${ }^{3}$ Champion GD, Day RO, Paull PD, et al. Clinical pharmacology and efficacy of benorylate in patients with rheumatoid arthritis. Aust NZ f Med 1978;8:22-8.

${ }^{4}$ Bender KJ. Salicylate intoxication. Drug Intell Clin Pharm 1975;9: 350-60.

' Anderson RJ, Potts DE, Gabow PA, Rumack BH, Schrier RW. Unrecognised adult salicylate intoxication. Ann Intern Med 1976;85: 745-8.

(Accepted 8 February 1984)

Department of Geriatric Medicine, Queen's University of Belfast and Belfast City Hospital, Belfast BT9 7BL

T R O BERINGER, MRCP, MRCPT, senior registrar

\section{Hypercalcaemia during resolution of calcinosis in juvenile dermatomyositis}

Calcinosis is common in juvenile dermatomyositis and may regress spontaneously. We report a case of juvenile dermatomyositis in which regression of pelvic calcinosis was associated with life threatening hypercalcaemia.

\section{Case report}

An 11 year old white boy was diagnosed as having dermatomyositis when he presented with proximal muscle weakness, a heliotrope rash, and a scaly dermatitis on the extensor aspect of his knuckles. Muscle enzyme activities were raised (serum creatine phosphokinase activity $331 \mathrm{U} / \mathrm{l}$ (normal 5-115 U/1)), and electromyographic findings were consistent with myopathy. He was treated with prednisone with good effect but required increasing doses after several relapses over the subsequent seven years.

In November 1980, at the age of 17, he sustained a minor blow to his left thigh and shortly after noted a painful lump in his left groin. Radiography showed calcinosis in the soft tissues around the left hip and thigh. This became more extensive over the next three months with resulting restriction in the movement of his hip. He developed anaemia and thrombocytosis; the erythrocyte sedimentation rate was $30 \mathrm{~mm}$ in the first hour and serum creatine phosphokinase activity $215 \mathrm{U} / \mathrm{l}$. Serum calcium and parathyroid hormone concentrations were not raised. In February 1981 the lump in his groin became fluctuant, and about $100 \mathrm{ml}$ of turbid material flecked with calcium was drained surgically, leaving a chronic sinus and severe residual calcinosis.

In January 1982 he developed a fever, vomiting, and malaise together with a tender swelling over his left buttock. Serum calcium concentration was $3.1 \mathrm{mmol} / 1(12 \mathrm{mg} / 100 \mathrm{ml}$ ) (normal $2 \cdot 07-2.52 \mathrm{mmol} / 1(8 \cdot 3-10 \mathrm{mg}$ ) $100 \mathrm{ml})$ ), serum phosphate concentration $1.59 \mathrm{mmol} / 1(4.9 \mathrm{mg} / 100 \mathrm{ml})$ (normal 0.9-1.6 mmol/1 $(2 \cdot 8-5 \mathrm{mg} / 100 \mathrm{ml}$ )), and serum albumin concentration $31 \mathrm{~g} / \mathrm{l}$. The urine calcium concentration was $6.6 \mathrm{mmol}(265 \mathrm{mg}) / 24 \mathrm{~h}$ (normal $1 \cdot 2-6 \cdot 2 \mathrm{mmol}(48-248 \mathrm{mg}) / 24 \mathrm{~h}$ ), serum parathyroid hormone concentration less than $0.05 \mu \mathrm{g} / \mathrm{l}$ (normal $0 \cdot 1-0.35 \mu \mathrm{g} / 1$ ), and serum 1,25dihydroxycholecalciferol concentration $24 \mathrm{pmol} / \mathrm{l}$ (10 ng/l) (normal 70$132 \mathrm{pmol} / 1(29-55 \mathrm{ng} / \mathrm{l}))$. He was treated with saline diuresis and increased doses of prednisone, but his serum calcium concentration remained raised.

Three weeks later, after complaining of weakness, nausea, constipation, and aching in the jaw, he had several grand mal convulsions and then remained unconscious. Serum calcium concentration was $3.53 \mathrm{mmol} / \mathrm{l}$ $(14 \mathrm{mg} / 100 \mathrm{ml})$ and serum magnesium concentration $0.6 \mathrm{mmol} / 1(1.5 \mathrm{mg})$ $100 \mathrm{ml}$ ) (normal $0 \cdot 7-1.4 \mathrm{mmol} / 1(1 \cdot 7-3.4 \mathrm{mg} / 100 \mathrm{ml}$ )). A computed tomogram of the brain was normal, but electroencephalography showed a severe abnormality over both cerebral hemispheres. He was treated with saline diuresis, phenytoin, and prednisone $100 \mathrm{mg}$ daily. After 36 hours he awoke suddenly, and over the next few days he recovered fully, although his serum calcium concentration remained raised at $2 \cdot 6-3 \cdot 2 \mathrm{mmol} / 1(10 \cdot 4-12 \cdot 8 \mathrm{mg}$ $100 \mathrm{ml}$ ). Acute hypercalciuria of up to $30 \mathrm{mmol}(1 \cdot 2 \mathrm{~g}) / 24 \mathrm{~h}$ was noted together with phosphaturia (index of phosphate excretion +0.45 (normal -0.3 to +0.3$)$ ), but urine hydroxyproline excretion was low at $0.08 \mathrm{mmol}$ $(10.5 \mathrm{mg}) / 24 \mathrm{~h}$ (normal $0-0.38 \mathrm{mmol}(50 \mathrm{mg}) / 24 \mathrm{~h}$ ), indicating that calcium was not being mobilised from bone.

Treatment was started with aminohydroxypropylidenediphosphonate $10 \mathrm{mg} / \mathrm{kg} /$ day. After one month, during which he remained well, the area of inflammation over his left buttock ulcerated and discharged large amounts of calcific material. The serum calcium concentration rose to $4.1 \mathrm{mmol} / \mathrm{l}$
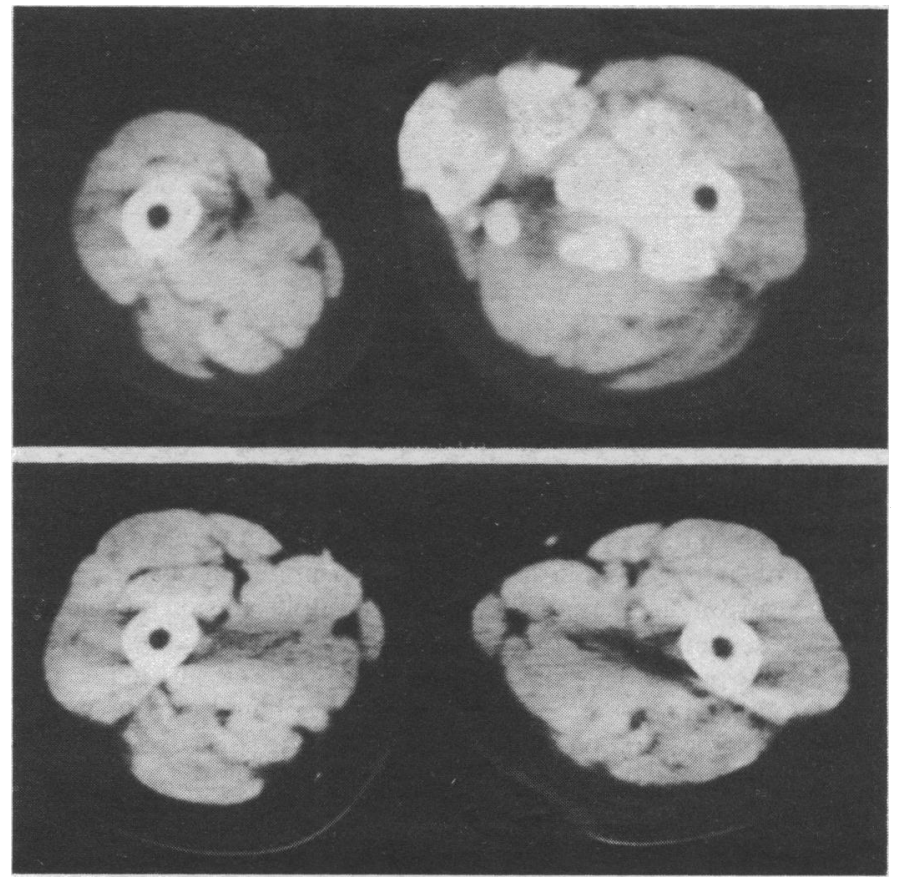

Top: Computed tomogram obtained in February 1981, showing extensive deposits of calcium density in extensor and adductor muscles of left thigh, extending to affect subcutaneous fat (adjacent unaffected thigh muscles are hypertrophied). Bottom: Computed tomogram obtained in March 1983, showing complete reabsorption of calcification; muscles in thigh are normal size.

$(16.4 \mathrm{mg} / 100 \mathrm{ml})$ but fell to $2.9 \mathrm{mmol} / 1(11.6 \mathrm{mg} / 100 \mathrm{ml})$ with saline diuresis. The ulcer continued to drain for two days, discharging roughly $400 \mathrm{ml}$, and then gradually healed with appreciable reduction in the swelling around the hip together with radiological evidence of regression of the calcinosis (figure). Subsequently he remained well with complete clinical and radiological regression of the calcinosis and normal serum calcium and parathyroid hormone concentrations. Steroids were gradually withdrawn. He showed no further evidence of dermatomyositis and achieved full puberty.

\section{Comment}

Calcinosis has an estimated incidence of up to $74 \%$ in patients who survive the active phase of juvenile dermatomyositis. ${ }^{1}$ Episodes of skin ulceration with extrusion of calcific debris are common and may be associated with cellulitis and systemic reaction, as in our patient. Spontaneous regression of calcinosis has been well documented, ${ }^{2}$ but associated hypercalcaemia has not previously been described. In our patient the suppressed serum parathyroid hormone concentration and low vitamin $\mathrm{D}$ and urine hydroxyproline concentrations together with extreme hypercalciuria and phosphaturia suggest that the hypercalcaemia developed as a result of spontaneous mobilisation of calcium from the calcific mass in the pelvis. Treatment with aminohydroxypropylidenediphosphonate did not appear to affect the serum calcium concentration and probably did not influence the outcome.

Professor C Alexander kindly reviewed the radiological findings in this report. The study was supported by a grant from the New Zealand Medical Research Council.

1 Muller SA, Winklemann RK, Brunsting LA. Calcinosis in dermatomyositis. Arch Dermatol 1959;79:669-72.

2 Sewell JR, Liyanage B, Ansell BM. Calcinosis in juvenile dermatomyositis. Skeletal Radiol $1978 ; 3: 137-43$.

(Accepted 8 February 1984)

Department of Medicine, Auckland Hospital, Auckland, New Zealand

M L WILSHER, MB, CHB, medical registrar

I M HOLDAWAY, MD, FRACP, endocrinologist

I D K NORTH, FRACP, FRCP, professor of medicine

Correspondence to: Dr $M$ Wilsher. 